\title{
Hydrogen evolution and consumption in AOT-isooctane reverse micelles by Desulfovibrio gigas hydrogenase
}

\author{
Susana L.A. Andrade*, José J.G. Moura \\ Departamento de Química, Centro de Química Fina e Biotecnologia, Faculdade de Ciências e Tecnologia, \\ Universidade Nova de Lisboa, 2825-114 Monte de Caparica, Portugal
}

Received 10 July 2001; accepted 6 February 2002

\begin{abstract}
The enzyme hydrogenase isolated from the sulphate reducing anaerobic bacterium Desulfovibrio gigas was encapsulated in reverse micelles of AOT-water-isooctane. The enzyme ability to consume molecular hydrogen was studied as a function of the micelle size (given by $W_{\mathrm{o}}=\left[\mathrm{H}_{2} \mathrm{O}\right] /\left[\right.$ organic solvent]). A peak of catalytic activity was obtained for $W_{\mathrm{o}}=18$, a micelle size theoretically fitting the heterodimeric hydrogenase molecule. At this $W_{\mathrm{o}}$ value, the recorded catalytic activity was slightly higher than in a buffer system $\left(K_{\text {cat }}=169.43 \mathrm{~s}^{-1}\right.$ against the buffer value of $151 \mathrm{~s}^{-1}$ ). The optimal buffer used to encapsulate the enzyme was found to be imidazole $50 \mathrm{mM}, \mathrm{pH} 9.0$. The molecular hydrogen production activity was also tested in this reverse micelle medium.

(C) 2002 Elsevier Science Inc. All rights reserved.
\end{abstract}

Keywords: Hydrogenase; Desulfovibrio gigas; Reverse micelles; Hydrogen production and consumption

\section{Introduction}

Reverse micelles are one of many model systems believed to possess properties that closely resemble those found in the biological cellular environment $[1,2]$. They are defined as solutions of amphipatic surfactant molecules that separate and stabilise an aqueous inner core from the outer organic solvent in such a way that the surfactant hydrophobic parts contact with the apolar bulk solution and the polar groups are faced towards an inner aqueous core. Although macroscopically homogeneous and thermodynamically stable, they can possess up to four different microenvironments: the hydrocarbon solvent, the surfactant molecules and the bound and free water in which any hydrophilic and/or hydrophobic molecule can partition according to its biochemical preferences [3-5]. Many enzymes have been studied in reverse micelles, always keeping or increasing their catalytic activity. Interestingly however, the enzymatic activity appears to be strongly dependent on the reverse micelle size, given by $W_{\mathrm{O}}\left(W_{\mathrm{o}}=\left[\mathrm{H}_{2} \mathrm{O}\right] /[\right.$ organic solvent $\left.]\right)$. A direct relation between the reverse micelle water content and its inner cavity core radius $\left(r_{\mathrm{m}}(\AA)=4+1.5 \times W_{\mathrm{o}}\right)$ was established, allowing microscopic information to be easily experimentally set $[6,7]$. Consequently, by varying $W_{\mathrm{o}}$ it is possible to mod-

\footnotetext{
${ }^{*}$ Corresponding author. Tel.: +351-21-2948382; fax: +351-21-2948550.

E-mail address: jose.moura@dq.fct.unl.pt (S.L.A. Andrade).

URL: http://www.dq.fct.unl.pt/bioin/
}

ulate the properties of the molecules: at $W_{\mathrm{o}} \leq 9$, the water inside the reverse micelle mainly hydrates the polar heads of the surfactant molecules (bound water) and present properties that closely resemble those of the water associated with a membrane structure [8]. As $W_{\mathrm{o}}$ increases, free water begins to appear and bell-shaped catalytic activity peak(s) may occur at the so-called "optimal" $W_{\mathrm{o}}$ value(s) [9]. In the case of multimeric enzymes, several "optimal" $W_{\mathrm{o}}$ can be observed [10], associated with the subunit(s) functionality. Ultra sedimentation assays concluded these "optimal $W_{\mathrm{o}}$ " to be related with a geometrical fit between the enzyme subunit(s) size(s) and the micelle inner radius [11].

In this work, Desulfovibrio gigas hydrogenase activity was studied in reverse micelles of sodium bis(2-ethylhexyl) sulfosuccinate (AOT), in isooctane. The periplasmic localisation of the enzyme in the bacteria cells, slightly associated with the membrane [12], anticipated the interest of using this system; the bound water characteristics $[8,13]$ closely associated with the surfactant molecules, structurally resembling phospholipid molecules and recognised as good models for biological membranes may provide hydrogenase a more favourable environment than that of any common buffer solution [14]. This $89.5 \mathrm{kDa}$ molecular weight enzyme has an average globular shape [15] and contains two different subunit. The small subunit with approximately $28 \mathrm{kDa}$ coordinates one $[3 \mathrm{Fe}-4 \mathrm{~S}]$ and two $[4 \mathrm{Fe}-4 \mathrm{~S}]$ clusters while the big subunit with about $60 \mathrm{kDa}$ contains the $\mathrm{Ni}-\mathrm{Fe}$ active site $[12,15]$. The hydration/membrane proximity 
relationship in the enzyme activity was investigated as a function of the micelle size following the enzyme ability to oxidise hydrogen. The proton reduction activity was also checked at a fixed $W_{\mathrm{o}}$, matching the theoretically "optimal" $W_{\mathrm{o}}$ fitting the heterodimeric molecule.

\section{Materials and methods}

All chemical reagents were of the highest purity available. AOT (Sigma) was kept in a dry atmosphere under vacuum in order to minimise traces of water molecules. All individual solutions were previously degassed under argon atmosphere before used. Methyl viologen (MV) (Sigma) was prepared in the appropriate buffer and sodium dithionite (Merck) was dissolved in $0.1 \mathrm{M}$ Tris- $\mathrm{HCl}$ pH 9.0 buffer to minimise traces of bi(sulphide) [16]. The required anaerobic atmosphere was achieved by carrying out all preparation steps inside an Atmos-bag (Aldrich) cycled with vacuum and argon gas (previously passed throw a heated copper system functioning as an oxygen trap).

\subsection{Enzyme purification}

All purification procedures were performed aerobically at $4{ }^{\circ} \mathrm{C}$ in Tris- $\mathrm{HCl} \mathrm{pH} 7.6$ buffer, according to methods described elsewhere [17]. The enzyme concentration was determined by its absorption intensity at $400 \mathrm{~nm}(\varepsilon 400 \mathrm{~nm}=$ $\left.46,500 \mathrm{M}^{-1} \mathrm{~cm}^{-1}[12]\right)$.

\subsection{Preparation of reverse micelles}

AOT reverse micelles were prepared according to the injection method [18]. In a typical experiment, an aqueous volume $(v)$ was added to the AOT in isooctane solution, according to the desired $W_{\mathrm{o}}$ by the equation: $v(\mathrm{ml})=$ $([\mathrm{AOT}] \times V(\mathrm{ml}) / 1000) \times 18 \times W_{\mathrm{o}}$, where $V$ is the total volume of the AOT solution and 18 the molar volume of water $\left(\mathrm{mol} \mathrm{ml} \mathrm{m}^{-1}\right)$. Immediately after the aqueous addition(s), the solution was well shaken until transparency (just a few seconds within the tested conditions).

Stock solutions of $0.2 \mathrm{M}$ AOT in isooctane, were prepared at least 1 day before use in order to assure solution stability.

\subsection{Hydrogen consumption activity}

The activity assays were performed at room temperature $\left(\sim 25^{\circ} \mathrm{C}\right)$ under anaerobic atmosphere. The hydrogen consumption was monitored by UV-VIS spectroscopy at $605 \mathrm{~nm}$ over time, following the parallel reduction of the electron acceptor, $\mathrm{MV}\left(\varepsilon_{605 \mathrm{~nm}}=13,000 \mathrm{M}^{-1} \mathrm{~cm}^{-1}\right)$, schematised in the equation below [12]

$$
\mathrm{H}_{2}+\mathrm{MV}^{2+} \rightarrow 2 \mathrm{H}^{+}+\mathrm{MV}^{+} \text {. }
$$

The reaction mixture was directly prepared in a quartz UV-VIS cell equipped with a rubber cap. The enzyme stock solution was previously exposed to hydrogen gas for about $1-2 \mathrm{~h}$ to reach the enzyme active state $[12,19]$. The reaction was then started by the addition of enzyme followed by an extra exposition to hydrogen gas for about 1-7 min (at constant flow) until a slight blue colour started to appear, corresponding to the reduced MV formation. The reaction progression curve could then be followed using a split beam UV-2101/PC Shimadzu spectrophotometer.

A tangent to the initial linear part of the reaction progression curve was drawn and initial velocities were calculated in $\mu \mathrm{mol}_{(\mathrm{MV} \text { reduced })} \mathrm{min}^{-1} \mathrm{mg}_{\text {(hydrogenase) }}{ }^{-1}$, for every tested MV concentration. The maximal velocity of the enzymatic reaction $\left(V_{\max }, \mu \mathrm{M} \min ^{-1}\right)$ and the Michaelis-Menten constant $\left(K_{\mathrm{M}}, \mathrm{mM}\right)$ were then calculated from Lineweaver-Burk linearizations. A minimum least square fit of the experimental points using a simple Michaelis-Menten equation [20] was also used to reconfirm the kinetic results and the catalytic activity $\left(K_{\mathrm{cat}}=V_{\max } /\left[\right.\right.$ hydrogenase], $\left.\mathrm{s}^{-1}\right)$ was determined.

The experimental conditions described above were used for the kinetic assays both in buffer and in reverse micelles in order to compare the enzyme behaviour in both systems.

\subsection{Hydrogen evolution activity in reverse micelles of $W_{o}=18$}

The enzyme ability to produce molecular hydrogen was measured by gas chromatography from solutions of dithionite reduced MV according to the reaction [21]

$\mathrm{MV}^{+}+2 \mathrm{H}^{+} \rightarrow \mathrm{MV}^{2+}+\mathrm{H}_{2}$.

The reaction mixture was prepared and sealed in vials inside the Atmos-bag under anaerobic conditions, as described above. To assure that the MV remained reduced inside the vials, some grains of sodium dithionite were added to the stock solution of $0.1 \mathrm{M}$ AOT in isooctane. After a short incubation at $37^{\circ} \mathrm{C}$ in a thermostatic bath the reaction was started by the enzyme addition and a fixed volume from the gas phase of the vial was taken with a gas-tight Hamilton syringe and injected into the gas chromatographer. Peak areas were recorded over time and the enzyme specific activity was calculated using a calibration curve, previously performed with known amounts of injected hydrogen gas.

The gas chromatograph, a Hewlett-Packard 5890 series II was equipped with a thermal conductivity detector (TCD) and the column used was an $2 \mathrm{nx} 1 / 8^{\prime \prime} \mathrm{SS}$ molecular sieves $5 \AA 100 / 120$. The injector temperature was set to $150^{\circ} \mathrm{C}$, the oven temperature to $100^{\circ} \mathrm{C}$ and the detector temperature was $200^{\circ} \mathrm{C}$. The carrier gas flow was $20 \mathrm{ml} \mathrm{min}^{-1}$.

\section{Results and discussion}

\subsection{Hydrogenase encapsulation in AOT reverse micelles}

Fig. 1 shows the UV-VIS spectra of hydrogenase encapsulated in $0.2 \mathrm{M}$ AOT reverse micelles varying $W_{\mathrm{o}}$ from 3 to 


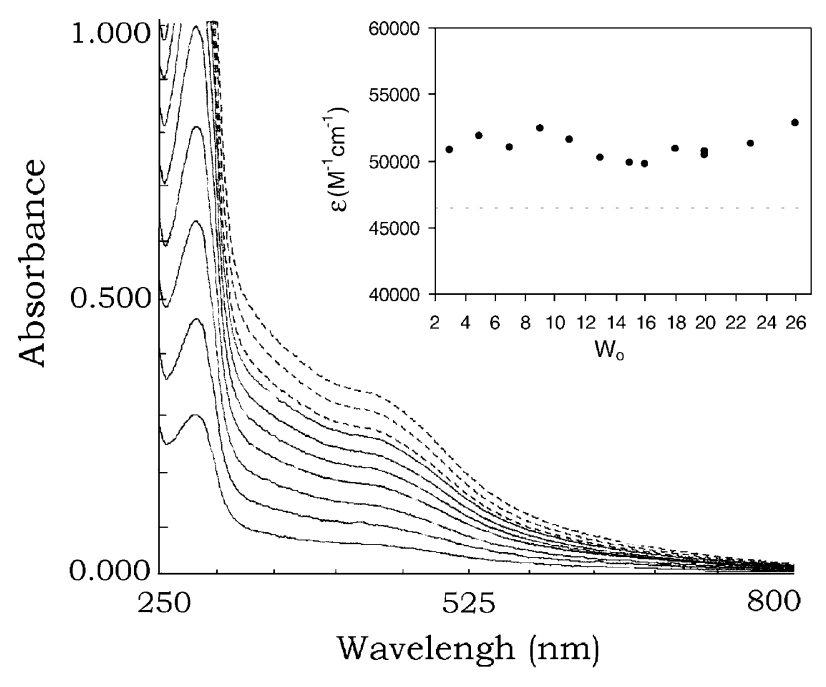

Fig. 1. UV-VIS spectra of encapsulated hydrogenase in $0.2 \mathrm{M}$ AOT reverse micelles as a function of $W_{\mathrm{o}}$ (3-26). Increasing amounts of $66.7 \mu \mathrm{M}$ hydrogenase stock solution were added to $1 \mathrm{ml}$ of $0.2 \mathrm{M}$ AOT solution in order to increase the aqueous volume in the solution and consequently the micelle size ( $W_{\mathrm{o}}=3$ to 26 , from bottom to top spectra). Inset: molar extinction coefficients calculated at $400 \mathrm{~nm}$, considering the protein concentration increments as $W_{\mathrm{o}}$ was varied. The broken line shows the extinction coefficient value reported for a buffer medium $\left(\varepsilon_{400 \mathrm{~nm}}=46,500 \mathrm{M}^{-1} \mathrm{~cm}^{-1}\right)$.

26. It is possible to conclude the protein overall conformation was kept since its spectra remained unchangeable over the tested experimental conditions. Moreover, the enzyme extinction coefficient at $400 \mathrm{~nm}$ was found stable at about $51,000 \mathrm{M}^{-1} \mathrm{~cm}^{-1}$, a value slightly higher than the one reported in buffer media. The extinction coefficient stability towards smaller reverse micelles is a clear indication that the absence of free water in favour of the more structured water (hydrating the surfactant molecules), does not significantly affect the protein. It should again be pointed out that hydrogenase is found in the periplasm of D. gigas cells and thus it is not surprising that an environment mimicking the highly structured water close to biological membranes does not highly perturb the enzyme.

\subsection{Hydrogen consumption as a function of the micelle size}

Fig. 2 shows the hydrogen consumption rates of hydrogenase solubilized in $0.2 \mathrm{M}$ AOT reverse micelles, at $W_{\mathrm{o}}=$ 18 under different buffer conditions. From these results it is clear that the enzyme is more active in $50 \mathrm{mM}$ imidazole buffer at $\mathrm{pH}$ equal to 9.0. In aqueous conditions, on the contrary, the optimal buffer conditions for the hydrogen uptake was reported to occur with Tris- $\mathrm{HCl}$ at $\mathrm{pH} 7.5-8.0$ [22]. The results can be explained considering previous reports indicating that the $\mathrm{pH}$ inside a reverse micelle can be shifted up to two $\mathrm{pH}$ units higher [23,24]. In this situation the initial buffer $\mathrm{pH}(\mathrm{pH}=9.0)$ could correspond to an aqueous

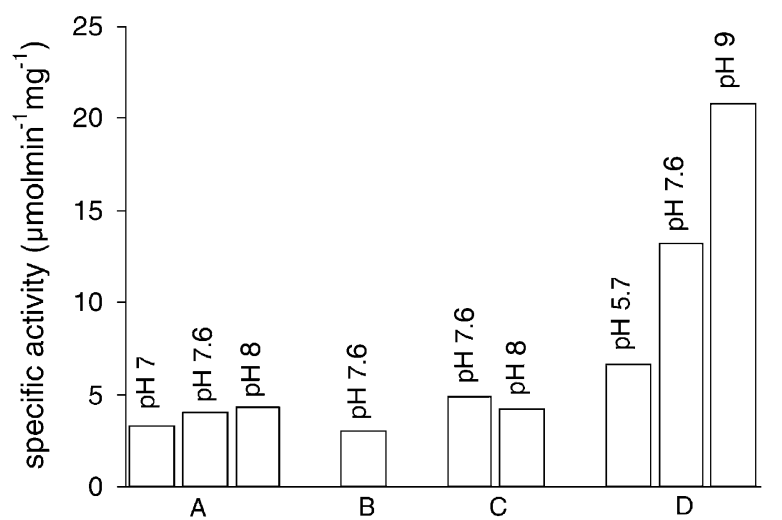

Fig. 2. Initial rates for the hydrogen oxidation reaction with several buffers and $\mathrm{pH}$ values in reverse micelles of $0.2 \mathrm{M}$ AOT at fixed $W_{\mathrm{o}}=20$. The activity tests conditions for hydrogenase encapsulated with several different buffers (A-Tris- $\mathrm{HCl} 20 \mathrm{mM}$; B-potassium phosphate $20 \mathrm{mM}$; $\mathrm{C}$-imidazole $20 \mathrm{mM}$; and $\mathrm{D}$-imidazole $50 \mathrm{mM}$, in the $\mathrm{pH}$ values stated in the graphic) were always kept constant and the UV-VIS cell had $1.5 \mathrm{ml} 0.2 \mathrm{M}$ AOT in isooctane, $46 \mathrm{nM}$ hydrogenase and $1.2 \mathrm{mM}$ methyl viologen.

core reverse micelle $\mathrm{pH}$ that closely mimic the reported optimal found for an aqueous medium. Regarding the imidazole results against Tris- $\mathrm{HCl}$ buffer, once more this seems to be a good buffer to consider in reverse micelle studies, as was demonstrated before using spin labelled reverse micelles (unpublished results).

The enzyme specific activity $\left(\mu \mathrm{mol} \mathrm{min}^{-1} \mathrm{mg}^{-1}\right)$ in this buffer (50 mM imidazole, $\mathrm{pH}$ 9.0) was also confirmed to be proportional to the enzyme concentration in the range of 46 to $92 \mathrm{nM}$ when encapsulated in $0.2 \mathrm{M}$ AOT reverse micelle of $W_{\mathrm{o}}=18$, while MV was kept constant at $2.5 \mathrm{mM}$ (data not shown).

Kinetic assays varying the MV concentration for each tested reverse micelle size $\left(W_{\mathrm{o}}\right)$ were also performed and are presented in Fig. 3 . The results confirm that the enzyme catalytic activity $\left(K_{\text {cat }}\right)$ is kept and, as expected, depends on the micelle size. The optimal experimental conditions to follow the hydrogen consumption occurred at $W_{\mathrm{o}}=18$. Moreover, at this point the catalytic activity $\left(169.43 \mathrm{~s}^{-1}\right)$ is slightly higher than the one we recorded under the same conditions in a buffer medium $\left(151 \mathrm{~s}^{-1}\right)$.

As mentioned before, the micelle inner cavity core radius $\left(r_{\mathrm{m}}\right)$ can be directly related to $W_{\mathrm{o}}$ by the equation: $r_{\mathrm{m}}(\AA)=$ $4+1.5 \times W_{\mathrm{o}}$. Furthermore, the mean protein radius $\left(r_{\mathrm{p}}\right)$ can be estimated to its molecular weight value, $M_{\mathrm{r}}\left(\mathrm{g} \mathrm{mol}^{-1}\right)$ by the equation: $r_{\mathrm{p}}(\AA)=0.7 \times\left(M_{\mathrm{r}}\right)^{1 / 3}[7,25]$. Taken together, this equations predict for hydrogenase an "optimal" activity peak at $W_{\mathrm{o}} \sim 18$, in agreement with our results.

Away from the "optimal" mentioned $W_{\mathrm{o}}$, the enzyme activity is rather low compared to the values found in buffer. For reverse micelles with $W_{\mathrm{o}}$ bigger than the "optimal" $\left(W_{\mathrm{o}}=20\right)$, the decrease in activity can be mainly explained by possible pH effects; as the micelle aqueous volume increases with increasing $W_{\mathrm{o}}$ the initial buffer $\mathrm{pH}$ (found 


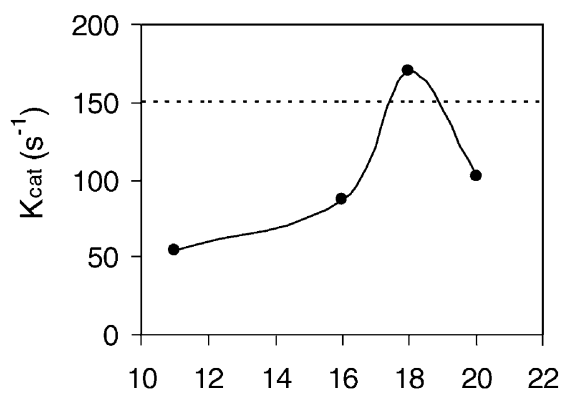

Fig. 3. Hydrogen consumption kinetic parameters found for hydrogenase encapsulated in $0.2 \mathrm{M}$ AOT reverse micelles as a function of the micelles size $\left(W_{\mathrm{o}}\right)$. Catalytic efficiency of hydrogenase in reverse micelles (top) and the enzyme specificity towards methyl viologen (bottom) for the hydrogen oxidation reaction, tested at micelle sizes fitting the small subunit $\left(W_{\mathrm{o}} \sim 11\right)$, the big subunit $\left(W_{\mathrm{o}} \sim 16\right)$, the heterodimer $\left(W_{\mathrm{o}} \sim 18\right)$ and at $W_{\mathrm{o}}=20$. Assays were always performed with $45 \mathrm{nM}$ hydrogenase encapsulated in $1.5 \mathrm{ml} 0.2 \mathrm{M}$ AOT in isooctane in imidazole buffer $50 \mathrm{mM}$ pH 9.0 and for different concentrations of methyl viologen. Each point represents a full kinetic assay and values are reported considering the overall micellar solution. Broken line in each graphic represents the value found in a buffer medium under the same experimental conditions.

optimal for $\mathrm{pH}=9.0$ with $W_{\mathrm{o}}=18$ reverse micelles) may no longer suffer the proposed shift towards lower values but become closer to the real added $\mathrm{pH}$. As already mentioned, the hydrogenase activity decreases for $\mathrm{pH}$ values away from $\mathrm{pH}=7.5-8.0[22]$.

\subsection{Enzymatic hydrogen production}

Hydrogen production by the enzyme encapsulated in reverse micelles was followed by gas chromatography at $W_{\mathrm{o}}=18$, following procedures previously described [17]. In Fig. 4 the hydrogen production assay, for $1.8 \mathrm{nM}$ enzyme, $\sim 2 \mathrm{mM}$ MV reduced with sodium dithionite in a total volume of $3.0972 \mathrm{ml}$, yielded a specific activity of

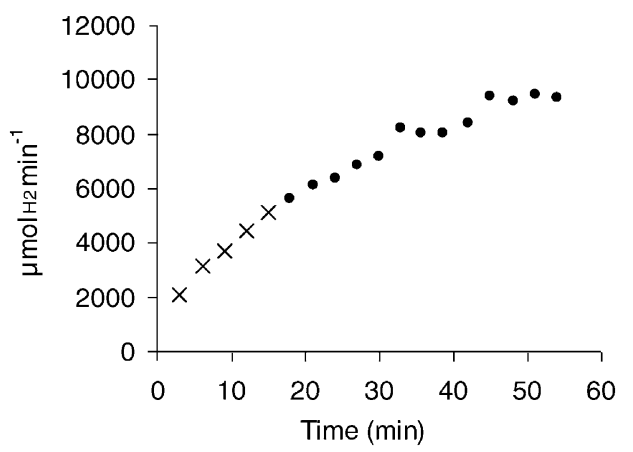

Fig. 4. Hydrogen production curve for hydrogenase encapsulated in reverse micelles of $0.2 \mathrm{M}$ AOT at $W_{\mathrm{o}}=18$. The hydrogen production followed over time in a reverse micelle solution with $\sim 2 \mathrm{mM}$ methyl viologen (sodium dithionite reduced) and $1.8 \mathrm{nM}$ hydrogenase in imidazole $50 \mathrm{mM}$ pH 9.0 buffer. Assay was measured at $37^{\circ} \mathrm{C}$ after enzyme addition. The points marked with $\mathrm{X}$ represent those used to draw a straight line $\left(r^{2}=0.9903\right)$ from which the specific activity was calculated.
$244 \mu \mathrm{mol} \mathrm{min}{ }^{-1} \mathrm{mg}^{-1}$. Although it is obvious the possibility to follow this reaction in reverse micelles it is also clear that the specific activity obtained was somehow low with respect to the aqueous activity found in the pure protein fraction, about $440 \mu \mathrm{mol} \mathrm{min}^{-1} \mathrm{mg}^{-1}[26,27]$.

\section{Conclusion}

We demonstrate here that the hydrogenase from the sulphate reducing bacteria $D$. gigas keeps its activity towards hydrogen consumption in a system that closely resembles the conditions the enzyme may find in a cell environment. As expected no peak of activity for the small subunit was detected since this $28 \mathrm{kDa}$ subunit contains the [3Fe-4S] and the $[4 \mathrm{Fe}-4 \mathrm{~S}]$ electron carriers clusters and not the $\mathrm{Ni}-\mathrm{Fe}$ active site, where the catalysis of protons or hydrogen is thought to occur. The decrease in activity observed for micelles bigger than the heterodimer size may be related with the tendency, as the bulk water predominates, for the external $\mathrm{pH}$ buffer to resemble the real $\mathrm{pH}$ inside the micelles, thus decreasing the activity as was found in buffer medium before.

The hydrogen production reaction, only tested for $W_{\mathrm{o}}=$ 18 , allow us to conclude on the possibility to follow this reaction in reverse micelles.

The study of this enzyme in the AOT/isooctane reverse micelle system is the last in a group of studies on the behaviour of flavodoxin [28] and aldehyde oxidoreductase (unpublished results) from $D$. gigas and cytochrome $c_{3}$ [29,30] in reverse micelles. These sets of $D$. gigas proteins were reported to be able to participate in an in vitro electron transfer chain starting with aldehyde catalysis by the aldehyde oxidoreductase enzyme and ending with molecular hydrogen production by hydrogenase [31]. The next step should be the encapsulation of all these proteins in reverse micelles, considering their individual behaviour in the previous reverse micelle studies and observe the electron transfer chain under these environmental conditions.

\section{Acknowledgments}

This work was supported by Fundação para a Ciência e Tecnologia, PRAXIS Grants 2/2.2/QUI/3/94 (I.M.), 2/2.1/BIO/05/94 (JJGM) and BD/11534/97 (SLA). We would like to thank M. Carepo and A. Pamplona for the hydrogenase samples used in this work and A. Levashov for helpful discussions.

\section{References}

[1] Bru R, Sanchez-Ferrer A, Garcia-Carmona F. Biochem J 1995;310:721-39.

[2] Martinek K, Levashov AV, Klyachko NL, Kmelnitsky YL, Berezin IV. Eur J Biochem 1986;155:453-68. 
[3] Hilhorst R, Spruijt R, Laane C, Veeger C. Eur J Biochem 1984;144:459-66.

[4] Nicot C, Vacher M, Vincent M, Gallay J, Waks M. Biochemistry 1985;24:7024-32.

[5] Drost-Hansen W, Clegg JS, editors. Cell-associated water. New York: Academic Press, 1979.

[6] Zulauf M, Eicke H. J Phys Chem 1979;88:480-6.

[7] Kabanov AV, Klyachko NL, Nametkin SN, Merker S, Zaroza AV, Bunik VI, et al. Protein Eng 1991;4:1009-17.

[8] Dáprano A, Lizzio A, Liveri VT, Aliotta F, Vasi C, Migliardo P. J Phys Chem 1988;92:4436-9.

[9] Levashov AV, Rarity RV, Martinek K, Klyachko NL. FEBS Lett 1993;336:385-8.

[10] Martinek K, Klyachko NL, Kabanov AV, Khmelnitsky YL, Levashov AV. Biochim Biophys Acta 1989;981:161-72.

[11] Kabanov AV, Nametkin SN, Evtushenko GN, Chernov NN, Klyachko NL, Levashov AV, et al. Biochim Biophys Acta 1989;996:147-52.

[12] Cammack R, Fernandez VM, Hatchikian C. Meth Enzymol 1994;243:43-69.

[13] Day RA, Robinson BH, Clarke JHR, Voherty JV. J Chem Soc, Faraday Trans 1979;75:132-9.

[14] Lysko AI, Surkov SA, Arutyunyan AM, Khmelnitsky YL, Klyachko IL, Levashov AV, et al. Biophysics 1986;31:252-8.

[15] Volbeda A, Charon M, Piras C, Hatchikian EC, Frey M, Fontecilla-Camps JC. Science 1995;373:580-7.

[16] Mayhew SG. Eur J Biochem 1978;85:535-47.
[17] Teixeira M, Moura I, Xavier AV, Moura JJG, LeGall J, DerVertanian DV, et al. J Biol Chem 1985;260:8942-50.

[18] Martinek K, Levashov AV, Klyachko NL, Berezin IV. Dokl Akad Nauk 1977;236:920.

[19] LeGall J, Ljungdahl PO, Moura I, Xavier AV, Moura JJG, Teixeira M, et al. Biochem Biophys Rev Commun 1982;106:610-6.

[20] Cornish-Bowden A. Fundamentals of enzyme kinetics. London: Portland Press Ltd., 1981.

[21] Rao KK, Rosa L, Hall DO. Biochem Biophys Res Commun 1976;68:21.

[22] Lespinat PA, Fauque G, Czechowski M, Dimon B, LeGall J. Biochimie 1986;68:55-61.

[23] Grandi C, Smith RE, Luisi PL. J Biol Chem 1981;256:837-43.

[24] Ohshima A, Narita H, Kito M. J Biochem 1983;93:1421-5.

[25] Levashov AV. Chemical and enzyme reactions. In: Berezin IV, editor. Surfactants in solution. Moscow: VINITI Publishers, 1987.

[26] Odom JM, Peck Jr HD. Ann Rev Microbiol 1984;38:551-92.

[27] Przybyla AE, Robbins J, Menon N, Peck Jr HD. FEMS Microbiol Rev 1992;88:109-36.

[28] Andrade SL, Kamenskaya O, Levashov AV, Moura JJG. Biochem Biophys Res Commun 1997;234:651-4.

[29] Lysko AI, Surkov SA, Arutyunyan AM, Khmelnitsky YL, Klyachko IL, Levashov AV, et al. Biophysics 1986;31:252-8.

[30] Castro MJM, Moura JJG, Cabral JMS. Advances in gene technology: protein production and purification, Miami, 1988.

[31] Barata BAS, LeGall J, Moura JJG. Biochemistry 1993;32:11559-68. 